\title{
ON THE CHARACTERS OF THE CARBONIFEROUS ROCKS OF
}

THE PENNINE SYSTEM.

BY WHEELTON HIND, M.D., B.S., F.R.C.S.

It is a well-known and undisputed fact that the Carboniferous succession of the Midlands differs very considerably from that which obtains in North Yorkshire, Northumberland, and Scotland, and the correlation of the Carboniferous sequence in various parts of Great Britain and Ireland has been a matter of difficulty and dispute. A study of the literature of the subject, voluminous and scattered though it be, seems to show one important fact, and that is that very few, if any, of the writers had studied the succession in more than one or two localities, or had given any attention to the evidence afforded by paleontology. To Yorkshire geologists, the sequence of the Carboniferous rocks in their county should be of the highest interest, not only on account of the large number of sections exposed in the romantic dales, for which the county is so justly famous, but because the change from the northern to the southern type of stratigraphical succession takes place in the county, and because, I am convinced, an accurate knowledge of the geology and paleontology of the Carboniferous rocks of the West and North Ridings will go far to settle the whole of the vexed question of correlation.

During the last five years I have published a series of papers on the correlation and sequence of the Carboniferous rocks of the Pennine axis and the south of Scotland, in which the following theses have been developed:-

(a) That the differences in the northern and southern types of the Carboniferous sequence is due to conditions brought about by the proximity of continental land to the north and north-east; that the main difference between the types is due to the very much greater amount of detrital material deposited as sediment in the area occupied by the northern type; that this area received the muds and sands brought down by a large river and deposited out at sea, 
HIND: CARBONIFEROUS ROCKS OF THE PENNINE SYSTEM. 423

thus hindering the deposit of the non-detrital but organic limestone, which went on uninterruptedly for a long period in the area occupied by the southern type of rocks.

(b) That the distribution of fossils shows most emphatically that the fauna of the Carboniferous Limestone of the southern type of rocks is identical with the fauna of the Great Scar Limestone and Yoredale series of the northern type. Hence the Yoredale series are the homotaxial equivalents of the upper part of the Carboniferous Limestone "massif" of the southern type, and do not in any sense overlie it. The comparative thickness of the Great Scar Limestone plus the Yoredale series and the mass of limestone further south further corroborates this view.

(c) That the detrital deposits of shales, dark limestones, and quartz-grits which overlie the massif of limestone in the southern area are not the equivalents of the Yoredale series; that this deposit is extremely local and lenticular, and that the boundaries of this lenticle can be fairly accurately mapped by measured sections, and that the fauna contained in these beds is entirely different from that found in the limestone massif below, and also from that of the Yoredale series of the northern type.

(d) That many Genera and species of Carboniferous fossils which occur low down in the Carboniferous rocks of Scotland appear for the first time at higher and higher horizons as the beds pass south, demonstrating a migration southward, and indicating a passage south of similar conditions of environment.

The evidence for these theses is given at length in a paper by Mr. Howe and myself, published in the Q. J. Geol. Soc., Vol. LVII, 1901 , and much of it need not be repeated here, but I propose to briefly review the chief stratigraphical and paleontological facts on which these views are based.

The southern type of Carboniferous rocks is well seen in the periclinal mass of limestone which occupies parts of North Stafford- 
424 HIND: CARBONIFEROUS ROCKS OF THE PENNINE SYSTEM.

shire and Derbyshire forming the tectonic centre of the great Pennine anticlinal. This mass, from 2,000 to $3,000 \mathrm{ft}$. thick, whose base has never been seen, is practically one mass of limestone, divided by very thin partings of shale into beds of stone, which are occasionally very thick and with very obscure bedding planes. In the quarry opposite the High Tor at Matlock and at Coombsdale the officers of the Geological Survey describe a thin coal and its underclay in the limestone. I have been informed that a piece of Stigmaria was obtained in the former locality.

The upper part of the Limestone is extremely variable, being thin bedded, thick, and crinoidal, massive and highly fossiliferous, or even cherty at apparently the same horizon in various places. But at or near the top is a bed containing many rolled water-worn shells and pebbles (?) of limestone, which is fairly constant over the whole area. At times the top of the limestone series is abrupt and sudden, and shales come on at once; at others there exists a welldefined series of passage beds of thin shelly limestones and shales, possibly a phase of the rolled shell bed, consisting of more comminuted but less rolled shell material. In places the upper 30 or $40 \mathrm{ft}$. of this Limestone Massif must have been a shell bank, for the limestone is made up of fossils, many of the shells being perfect, but others being slightly eroded; but, evidently, from the fact that all kinds of fossils are present massed and jammed together, not exactly in the place where all lived, but while there is no doubt that some species were able to and did live on the bank, the shells of others were washed there by currents.

At Castleton and Waterhouses the bed of rolled shells consists chiefly of fragments of Productus giganteus, but this shell occurs again in the next 15 or $20 \mathrm{ft}$. which forms the top of the limestone. This line is at once the upper limit of the massive limestone and of $P$. giganteus, for in this district this shell does not appear again at any higher horizon.

The massif of limestone is succeeded by a series of black shales and thin limestones, for which I have adopted the name PendeESIDE SerIes, with a peculiar fauna of Posidonomya Becheri, P. membranacea, Posidoniella losvis, P. minor, Chenocardiola Footi, Pterino- 
HIND : CARBONIFEROUS ROCKS OF THE PENNINE SYSTEM. 425

pècten papyraceus, Glyphioceras reticulatum, G. spirale, G. bilingue, and other species, none of which occur below. Only a few brachiopoda of the Carboniferous Limestone pass up into these beds, but the peculiar fauna enumerated above recurs at various horizons in the Millstone Grit series and lower coal measures. The limestones become thinner and thinner, and towards the top of the series sandstones and quartzose gannisters appear in the shales, and become more and more pronounced until the Grits come on. So much for the general sequence in Derbyshire.

The sections from Pendle Hill to Clitheroe show a sequence perfectly parallel to that which obtains in Derbyshire. The shelly detrital beds and crinoidal limestones being specially well marked. Very fine and almost complete sections are to be seen in the Angram and Pendleton Brooks, and the cloughs on the west flank of Pendle Hill. These beds yield a typical fauna, as may be noted by an examination of Appendix B (page 461).

The sections in the Massif of limestone near Clitheroe show a white massive limestone full of shell fragments or made up of crinoids at the top, while lower down, as at Chatburn, a series of dark blue limestones with their shale partings are in evidence. Further west inliers of the Limestone Massif, consisting of the upper and fossiliferous beds, protrude through the Pendleside shales at Withgill, Ashnot, Doe Barn, Whitewell, Chipping, Sykes, and Slaidburn, at which places good specimens of the typical fossils of this horizon can be obtained. The beds at Sykes were largely altered by vein stuff, but contain Amplexus coralloides and Lithostrotion sp. The Pendleside series are to be seen in the brook courses and a few quarries round these inliers at Black Hall and Cold Coates, S.W., and Thornley Hall, south of Chipping; the river Hodder; quarries below the Longridge Fell escarpment; below Ashnot Barn; Holden near Bolton-by-Bolland; streams at West Bradford and Grindleton; the river Ribble near Dinckley Hall ; and the typical fauna of the series has been obtained at all these localities.

A most interesting set of beds oceur at or about the top of the Limestone Massif, along a line extending from Thornton to Barnoldswick. This is an anticlinal hill, a N.E. and S.W. axis, the limestone 
426 HIND: CARBONIFEROUS ROCKS OF THE PEXNINE SYSTMM.

beds forming the limbs of the anticlinal being very thin and separated by shales, which, toward the top, become fairly well developed. This portion of the limestone is a southerly continuation of the anticlinal of Haw Bank and its continuation to Bolton Abbey, and its secondary folds round Draughton. Here, the upper part of the limestone Massif is split up by shale beds, which attain some little thickness. Sections at Rain Hall and Gill rock quarries, Barnoldswick, show this condition of deposit very clearly. Further south-west a similar set of beds are seen in the Lancashire and Yorkshire Railway, one mile north of Riminington Station, and still further S.W. at the large quarry two miles south of Chipping.

I consider the beds along this line to be a local phase of the close of the limestone deposit, probably due to a current which brought detrital sediment and deposited it in a definite and strictly limited area. The fauna of the shales intercalated with these limestones is peculiar and interesting. At Draughton, in a small quarry near the railway, the shales yielded a fine specie of Ctenacanthus tenuistriatus.

The limestones at Draughton yielded Cardiomorpha ovata, and the Rev. A. Crofton tells me he has obtained species of Spirifer, Productus, Phillipsia, and Corals here.

At Thornton Quarries I obtained-

Cladochonus sp. Very frequent.

Palæchinus sphcericus. Very frequent.

Crinoid-stems.

Conocardium Hibernicum.

The following specimens were found at Rain Hall Quarries :-

Cladochonus sp.

Palochinus sphoricus.

Crinoid-stems, three species.

Productus semireticulatus.

Orthotetes crenistria.

Athyris planosulcata.

Conocardium aliforme.

Syringopora geniculata.

Zaphrentis Enniskilleni. 
HIND : CARBONIFEROUS ROCKS OF THE PENNINE SYSTEM

The Chipping Quarry also yielded-

Palcechinus sphoricus.

Many Crinoid-stems.

Chonetes papilionacea.

Productus semireticulatus.

Productus longispinus.

Spirifer trigonalis.

Orthis Michelini.

Ccelonautilus cariniferus.

This series of fossils is altogether distinct from the fauna of the Pendleside series, but on the other hand many of the fossils obtained at the top of the Massif of Limestone are absent in these localities, a fact probably due to the conditions under which deposition took place. Palcechinus sphoricus and Cladochonus, so common in these calcareous muds, are rare in the limestone itself. A very similar local deposit with a similar fauna occurs in the neighbourhood of Bradbourne, Derbyshire, also situated at the top of the Limestone Massif.

I regard the appearance of this set of shales in the massive limestone, so far south of and altogether independent of the Craven faults, as important. The presence of this muddy deposit indicates that the Yoredale phase was not restricted by these faults, and consequently that the faults could not possibly have had any causal influence on the different character of the deposits of the northern and southern types. The extent to which muddy sediment was carried out to sea would vary very largely, being affected amongst other causes by currents, the formation of bars, and the size and flow of the river bringing down sediments. Consequently, the area, where a pure and continuous deposit of calcareous ooze was going on, would be liable to temporary invasion, resulting in a series of shales becoming intercalated in a limestone deposit, the general facies of the fauna remaining unchanged.

Further north, the Limestone Massif is thrown up in the Craven district, where it forms a long anticlinal, which has been peculiarly scarped into rounded domes, from Greenhow Hill, on the east, to 
428 HIND: CARBONIFEROUS ROCKS OF THE PENNINE SYSTEM.

Cold Coniston, on the west. This limestone is the usual massive, white form, crammed with shells, like that seen at Clitheroe, and the great fossil localities of Derbyshire and Staffordshire, and moreover contains an identical fauna. It is known to be overlaid by shales and a black limestone below Thorpe and Rylstone Fells, which contain the typical Pendleside fauna. But a most instructive and interesting section is to be seen on the south side of Dibbs Bridge, about four miles east of Grassington, on the Pateley Bridge road, which is identical with the section at the foot of the Winnats, at Castleton, containing a bed which Messrs. Barnes and Holroyd have described as a beach bed (Trans. Manch. Geol. Soc., Vol. XXV., page 119).

The section shows--

Post of limestone with shell fragments and Productus giganteus. 15 feet.

Post of shelly limestone not much rolled. About 10 feet.

* Bed of rolled shells, lenticular shell fragments, and rolled pieces of limestone. 4 feet.

Post of limestone with many specimens of Productus giganteus. 6 feet.

Hard blue limestone. 15 feet.

The bed marked * is quite undistinguishable from the similar bed at Castleton. I saw several samples of this rock some four miles further west, on the road between Threshfield and Linton, and Threshfield and Grassington, in the stones piled for road-making. In this I got the peculiar dark masses of foraminiferal limestone imbedded in white limestone, which Messrs. Barnes and Holroyd have recently described. The exact similarity of the upper beds of the limestone of Craven and Derbyshire is very striking, and at any rate points to similarity of conditions of deposit. I myself believe that the two sets of beds are on the same horizon. and present a well-marked stratigraphical line. In the Craven district the Pendleside series quickly thins out, so that from Appletreewick to Greenhow Hill, and for some distance from Grassington northward, the grits immediately overlie the Limestone Massif, and nowhere north of a line passing from Settle, via Malham, to Hebden (Wharfedale) has the Pendleside fauna been yet obtained, but it occurs in the shales in the 
HIND: CARBONFEROUS ROCKS OF THE PENYINE SYSTEM. 429

Wharfe near linton stepping stones, and in the beds seen in the brooks between Burnsall village and the grits of Thorpe Fell. North of the Wharfe I got Posidoniella lavis in shales near the bridge over Hebden Gill and the bank opposite St. Michael's Church, Linton. In shales in the river Wharfe, near the stepping-stones at Linton, I got Posidonomya membranacea in abundance, with remains of Goniatites. It has generally been taught that the knolls of limestone in Craven are the representatives of the Pendleside Limestone, in spite of the fact that the stratigraphical succession of the Thorpe, Cracoe, and Pendle-Clitheroe districts are identical, that the limestones of Clitheroe and Cracoe are exactly similar in composition, and both are altogether different from the Pendleside Limestone, and notwithstanding the fact that the faunas of the Clitheroe and Cracoe Limestones are identical and differ entirely from that of the Pendleside Limestone, and that the latter fauna is abundantly present in the shale series which immediately succeds the limestone of the knolls. Nor are the knolls themselves on different horizons, but they belong to the same anticlinal fold cut into domes by small water courses and the sub-aerial action of water containing $\mathrm{CO}_{2}$ in solution, and therefore not always weathered equally, by which I mean that different posts of limestone are to be seen on the different hills.

Between Butterhaw and Hill Skelterton is a fairly large swallow hole, in the upper part of which is seen a section of shales enclosing a black limestone, dipping at an angle that I think quite sufficient to carry them over the white limestone, but if not, the true position may have been altered by the undermining which has occurred in the swallow. The black limestone is crammed with Posidonomya Becheri, Posidoniella lavis, and Glyphioceras reticulatum.

The presence of the Pendleside Limestone is thus demonstrated above the white limestone of the knolls, and the closeness of the bed to the white limestone of the swallow also shows the rapid thinning away of the mass of shales, which, at Pendle Hill, separate the Pendleside Limestone from the Clitheroe Limestone. This thinning away of the Pendleside series is borne out by the presence on Simondseat of swallow holes in the Grit, which shows that the limestone is no great distance below the surface. North of Grassington and almost 
as far north as Kettlewell the Grits repose on the thick limestone, showing that the Pendleside series has quite disappeared.

Mr. Tiddeman quotes a conglomerate bed which he thinks has been formed by masses of white limestone rolling down from clifis or reefs of limestone and becoming embedded in shales deposited subsequently round these hypothetical structures. There is a crushed bed of limestone which might be called a conglomerate in a stream section east of Keal Hill, but unfortunately for this view the masses of limestone are not white, nor do they contain the fossils of the socalled reefs and chemical analysis shows that the latter limestone contains 97.5 per cent. of $\mathrm{CaCO}_{3}$ and $\cdot 6$ per cent. of silica, the limestones in the conglomerate (?) containing $36 \cdot 7$ per cent. of $\mathrm{CaCO}_{3}$ and $54 \cdot 0$ per cent. of silica.

The country between the Midland Railway and the boundary of sheet 60 of the one inch ordnance map is largely mapped as shales, through which some few inliers of limestone appear. An examination of the area, the numerous quarries, the contour of the ground, the absence of trees, boggy ground and streams point to a far larger area of limestone than is mapped.

Commencing on the west, the side of the fell at Tosside shows at the Knotts a massive white limestone cropping out below the grit as a lenticular patch, but, owing to absence of stream sections, its extent cannot be well traced downwards. This limestone is lithologically quite different from the Pendleside type, and contains a characteristic Carboniferous Limestone fauna.

Corals.

Lithostrotion and Zaphrentis.

Crinoids.

Chonetes papilionacea.

Productus margaritaceus.

Productus giganteus.

Glyphioceras crenistria, \&c., \&c.

About three-quarters of a mile north of this, in an exposure behind the farm at Brockthorns, is another very interesting section, the beds being almost horizontal. This shows at the top:- 
HIND: CARBONIFEROUS ROCKS OF THE PENNINE SYSTEM. 431

Dark soft shales, $3 \mathrm{ft}$.

Limestone composed of rolled shells, corals, crinoids, and fragments of limestone, comparable to the Beach Bed of Castleton, $3 \mathrm{ft}$.

Shales, $2 \mathrm{ft}$.

Shaley limestone, $1 \mathrm{ft}$.

Shales, $1 \mathrm{ft}$.

Thick limestone, $6 \mathrm{ft}$. to sole of quarry.

At the north end of the quarry the middle beds are disturbed and folded, but the upper and lower limestone are not affected.

The fauna here is extensive. Some of the calcareous shales are crammed with crinoid joints and fragments of Palæchinus. The shelly limestone contains :--

Glyphioceras crenistria.

, sphoricum.

Rhynchonella pleurodon.

Productus giganteus.

", longispinus.

, striatus.

" semireticulatus.

Chonetes papilionacea.

Spirifera trigonalis.

, lineata.

, glabra.

Dielasma sacculus.

Strophomena analoga.

Lithostrotion Martini.

Crinoids sp. 3.

A very noticeable feature in a rolling hill passes south from this quarry in the direction of the Knotts, which we cannot but think indicates a continuance of the limestone.

About a mile and a half north-west a narrow lenticle of limestone is mapped. In this occur an interesting series of quarry sections showing a similar series to the Brockthorns quarry. 
432 HIND: CARbONIFEROUS ROCKS OF THE PENNINE SYSTEM.

The quarry at the dip mark, north of the word Bollards, shows the following sequence:-

Crinoid limestone, 3 in.

Black shale, 4 in.

Finely stratified limestone, 9 in.

Gypsum, 1 in.

Black shale, 3 in.

Platy limestone, 3 in.

Crinoidal limestone, 2 in.

Black shales, $2 \mathrm{ft}$. 3 in. with Productus longispinus,

Crinoidal limestone, 5 in.

Earthy limestone, $2 \mathrm{ft}$.

Solid limestone, $15 \mathrm{ft}$. Base not seen.

The following fossils were obtained :-

Productus mesolobus.

, plicatilis.

, punctatus.

" semireticulatus.

Spirifera trigonalis.

At Pythorns, a little more than a $\frac{1}{4}$ mile further east, the conglomerate bed of Brockthorns is again seen crammed with rolled fossil débris about $3 \mathrm{ft}$. thick. This is covered in by a few inches of shales, while below is fairly massive but well-bedded limestone, with hands of apparent breceiation.

The following fossils were obtained:-

Zaphrentis.

Crinoids.

Phillipsia sp.

Productus giganteus.

punctatus.

Spirifera lineata.

" glabra.

Orthis resupinata.

„ Michelini.

Spines of Palcechinus.

Euomphalus Dionysii? 
HIND: CARBONIFEROUS ROCKS OF THE PENNINE SYSTEM. 433

Two miles still further east is the quarry at Teenly Rock, which shows fine well-bedded limestone, the beds being nearly horizontal. Towards the base of the quarry is a bed of oolitic limestone. Fossils are not plentiful here, but a typical Carboniferous Limestone fauna occurs :-

Productus giganteus.

" semireticulatus.

" plicatilis.

, punctatus.

Spirifera glabra.

" lineata.

Athyris planosulcata.

Orthotetes crenistria.

Orthis resupinata.

Conocardium aliforme.

Crinoidal fragments.

Between Teenley and Pythorns thin limestone and shales are seen in the stream at Becks Brow Bottom, and a sulphuretted hydrogen spring, indicating a roll and temporary disappearance of the limestone from the surface.

East of the Ribble is a patch of country bounded on the north and east by the Hellifield and Skipton line. Numerous dip marks and quarries are shown, nearly all of which show the upper beds of the massif of limestone. The country has a rolling domed contour which we have found to be characteristic of limestone rather than shale areas and is moreover covered by stone walls, and is treeless and waterless. Massive bedded limestone is seen in a quarry just beyond Bell Busk station, and another quarry rather less than $\frac{1}{4}$ mile west of Bell Busk viaduct. This shows $18 \mathrm{ft}$. or more of thick massively bedded limestone with no shales, and yielded the following fossils :-

Chonetes papilionacea.

Spirifera lineata.

Syringopora geniculata.

Cyathophyllum Stutchburyi.

Crinoids. 
434 IIND : CARBONIFEROUS ROCKS OF THE PENNINE SYSTEM.

The Cold Coniston limestone mapped as isolated beds, regarded in connection with the beds exposed in the hill 200 yards west, are evidently more extensive.

This limestone occurs in a series of domes or knolls, one of which is bisected by the Skipton-Settle road at Fogga.

The upper part of this limestone is massive, not well bedded, whitish in colour, but the lower beds are more regularly stratified. A fairly extensive fauna, typical of the Carboniferous Limestone, occurs here.

Two hundred yards west is another quarry on the south side of the road in the side of a large well-rounded rolling hill. The beds are well marked, and dip at $30^{\circ}$ N.N.E., and thus would, if produced, pass below the limestones of Fogga.

About $30 \mathrm{ft}$. of beds are exposed.

The following fossils were obtained:-

Productus semireticulatus.

Spirifera glabra.

Rhynchonella pleurodon.

LARge Corals.

Cyathophyllum Stutchburyi.

Zaphrentis cylindrica.

Three-quarters of a mile further west and a little north, another exposure is found in a wood at Old Rock plantation, on the 1 inch map

Here several feet of well-bedded limestones covered by black shales are seen dipping N.W. at $15^{\circ}$.

On the rolling ground south of the road are the following sections. A little more than $\frac{1}{4}$ mile S.S.W., at the word quarry on the 1 inch map is the following section:-

Hard blue limestone. $1 \mathrm{ft}$.

Hard nodular shale with crinoids, Zaphrentis, and fragments of shells. $12 \mathrm{ft}$.

Well-bedded limestone.

Half a mile south-east, between the woods Camp and Hall Field, are two exposures in the same beds, showing massive well-bedded grey limestone overlaid by calcareous shales. 
HIND: CARBONIFEROUS ROCKS OF THE PENNINE SYSTEM. 435

The limestone yields Productus giganteus, and a very large coral, Cyathophyllum Stutchburyi, and Crinoid débris.

The dip varying from $10^{\circ}$ to $20^{\circ}$ almost due north.

About three-quarters of a mile west of the above, five exposures are seen in the high banks of the northern tributary of the Swinden Beck. Both exposures have been quarried.

The most northern quarry shows-

Shale, becoming calcareous at base. $6 \mathrm{ft}$.

Hard compact limestone. $2 \mathrm{ft} .3 \mathrm{in}$.

Earthy shale. 9 in.

Hard limestone, base not seen. $6 \mathrm{ft}$.

Talus. $12 \mathrm{ft}$.

Dip a little W. of N. $10^{\circ}$ to $20^{\circ}$.

The middle quarry continues the section downwards, and shows several feet of hard massive limestone with the large corals, Cyathophyllum Stutchburyi and Zaphrentis cylindrica.

The lowest quarry still continues the section downwards, and shows a further $18 \mathrm{ft}$. of well-bedded thick limestones and no shales.

Unfortunately, a gap in the sequence occurs here, but almost a hundred yards south the stream shows a succession of black shales, the exact position of which is doubtful, but a series of dark limestones of Pendleside type occurs in them just east of the railway in Swinden Gill。

Further north massive limestone is seen between the Craven Faults, and is well exposed in the scars of Malham, Settle, and Giggleswick. The upper beds at Malham and Settle yield the usual rich fauna of the Carboniferous limestone. No trace of any interstratified shales or sandstones are to be seen.

The shale series which underlies the Millstone Grit rocks west of Malham is shown by its fossils to belong to the Pendleside series (Hind and Howe, of supra. cit, pp. 359, 360), and possibly some of the shales immediately below the grits of Black Hill may belong to this series. But there is a thin limestone which is seen in a stream a quarter of a mile west of Black Hill, which contains Productus latissimus, and is therefore shown to belong to the Yoredale series. At Chattering Sykes, in Outside Grizedale, is a spring which washes 
out numerous fossils. This water has evidently pierced a limestone by a swallow, and is thrown out by a fossiliferous bed of shale which underlies it. The passage of the subterranean stream over the fossil bed washes out numerous fossils, amongst which are-

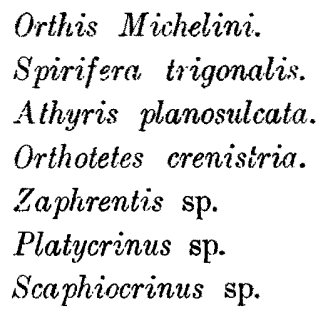

The fauna in this bed is, therefore, totally different from that characteristic of the Pendleside series, and demonstrates that the beds have some relation to the Yoredale series of Wensleydale.

An interesting section is seen in the brook east of Scaliber Force, commencing where the road to Kirkby Malham crosses the stream by a culvert :-

Sandstone with a curiously mammillated under surface, 3 feet.

Sandy shales, 9 feet.

Hard quartzose sandstone, 3 feet.

Black shales with bullions, 20 to 30 feet.

A fault passes across the shales, and where the shales are contorted several masses of limestone oceur with large corals, Productus giganteus, Spirifera trigonalis, Athyris planosulcata, and crinoids. Below the disturbed shales, the stream section shows more shales dipping regularly and not contorted. It is very doubtful indeed if these fossils are in situ, but the masses of limestone seem to me to have been dragged in along the fault and crumpled up, as the seam of limestone is not apparent anywhere else in the stream section.

Negative evidence is important at this spot. Nowhere is there to be seen between the Millstone Grit and the top of the Carboniferous Limestone any beds corresponding to the Yoredale series of Wensleydale.

The western boundary of the Yoredale phase of Rocks is fairly well marked, the great splitting up of the main mass of limestone does not seem to take place west of a north and south line passing through 
HIND: CARBONIFEROUS ROCKS OF THE PENNINE SYSTEM. 437

Kirkby Lonsdale, though one well-marked bed of yellowish-white limestone is to be seen in shales north of Whittington village. Unfortunately no fossils were found either in the stream section or the small quarry; but between this bed and the Massif of Limestone, in a small stream, a quarter of a mile south of Sellet Hall, a calcareous shale with nodules yielded :-

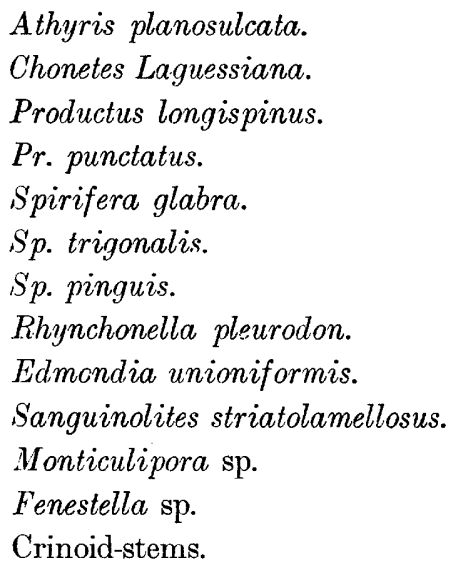

The study of the belt of Carboniferous rocks deposited round the older rocks of the Lake District is of interest and importance. On the eastern side the base of the Carboniferous rocks is seen in the neighbourhood of Shap, where the basement beds have the character of a conglomerate. Around Carnforth and as far east as Kirkby Lonsdale, there is no evidence that the Carboniferous Limestone is sub-divided by intercolations of shale and sandstone, and the limestone here is at least 500 feet thick ; but east of Shap the limestone is split into well-marked beds, of which the lowest is the Ship Limestone, and the next in series is the Knipe Scar Limestone. The latter yielded me-

Lithostrotion junceum.

Cyathophyllum regium.

Athyris planosulcata.

A. globulina.

A. expansa. 
438 HIND: CARboniferous RoCks OF THE PENNINE SYSTEM.

Chonetes papilionacea.

Ch. Buchiana.

Dielasma hastatu.

Productus cora.

Pr. giganteus.

Spirifera trigonalis.

Sp. lineata.

Syringothyris cuspidata.

Orthotetes crenistria.

Edmondia sulcata.

Solenopsis minor.

Euomphalus pentangulatus.

E. cirrus.

Loxonema sp. (cast).

Naticopsis plicistria.

Orthoceras Breynii.

Cephalopod fragments.

The lowest or Shap Limestone yielded large masses of Choetetes tumidus, Cyathophyllum regium, Syringopora ramulosa, Chonetes papilionacea, Productus giganteus, Spirifera glabra, Sp. pinguis near Askham and Rossgill, and plant remains near Shap.

The list of fossils given on pp. 85-88, Mem. Geol. Surv., Geol. Country round Kendal, \&c., is fairly long and accurate; the nomenclature of the lamellibranchs and cephalopods, however, needs revision, but it will be sufficient here to point out that Edmondia sulcata and Prolecanites compressus, so characteristic of the lower limestones of Scarlet and Ballasalla, Isle of Man, also occur here.

Very valuable contributions to our knowledge of the Carboniferous Rocks on the south and east of the Lake District, have been made by Mr. J. D. Kendall, F.G.S. His papers on the hematite deposits of Furness and West Cumberland, and the Carboniferous Rocks of Cumberland and Furness, are published in the Trans. N. Eng. Inst. M. Mech. Engineers, Vols. XXVIII., XXXI., and XXXIV. In the latter, especially, he shows that the Carboniferous Limestone in Furness, i.e., to the south of the Lake District, is almost undivided by shales, but that as it passes north shales and sandstones set in and split up the mass. 
HIND: CARBONIFEROUS ROCKS OF THE PENNINE SYSTEM. 439

In West Cumberland he gives the following section as obtaining from Ullock to Egremont :-

1st or Langhorn Limestone, 30 to 60 feet.

Shales, 10 to 14 feet.

2nd Limestone, 14 to 24 feet.

Sandstones and shales, 40 to 60 feet.

3rd Limestones, 10 to $\mathbf{1 6}$ feet.

Shale, 2 to 6 feet.

4th or Clint's Limestone, 235 to 310 feet.

Shale or sandstone, 14 to 24 feet.

5 th Limestone, 50 to 70 feet.

Shale, sandstone, or thin limestones, 14 to 24 feet.

6th Limestone, 54 to 70 feet, or 105 at Lamplugh.

Shale, thin and variable.

7 th Limestone, 40 to 182 feet.

Shale.

Skiddaw Slate.

This shows a proportion, taking the greatest thicknesses, of 757 feet of limestone and 130 feet of detrital rocks.

During the last few weeks I have examined several quarries and sections at Bigrigg, Yeathouse, Rowrah, and Lamplugh, and although fossils are not very common I obtained Productus giganteus at all these places. The Yeathouse Quarry gives the following section, the beds dipping west at about $20^{\circ}$.

Limestone massive, beds much mottled with

Productus giganteus, 50 feet.

Bluish Limestone with peculiar black inclusions, with

Productus giganteus, 30 feet.

, semireticulatus.

Edmondia sulcata.

, Lyelli.

Solenopsis minor.

Solenomya primava.

Pinna flabelliformis.

Loxonema sp.

Grey Limestone, with Productus giganteus and Productus cora, 40 feet. 
440 HIND: CARBONIFEROUS ROCKS OF THE PENNINE SYSTEM.

Shale, 2 feet.

Thin Limestone, 1 foot 6 inches.

Shale, 4 feet.

Sandstone, 2 feet.

Sandy Shales, 6 feet.

Shales, 6 feet.

Limestone, 75 feet.

In his Furness paper (Op. supra eit., Vol. XXXI., page 215), Mr. Kendall estimates, from borings and sections, the thickness of the limestone in the Furness district as 946 feet, and this mass contains only about 34 feet of interbedded detrital rocks.

Above the mass of the limestone of Furness shales with limestones are to be found, and it will be a matter of importance to ascertain whether they contain the Pendleside fauna or not. Personally I have only examined the shales in the stream section north of Borwick Hall. A series of sandy and muddy shales with sandstones were seen, but the only fossils obtained were fragments of plant remains and scales of Megalicthys Hibberti.

Unfortunately no paleontological evidence is mentioned in Mr. Kendall's paper, but the important fact remains that during the deposition of the limestone, currents bearing detrital mud and sand did not reach Furness to any extent, but they did reach the district of West Cumberland, and caused the division of the limestone into distinct beds.

The plates of Mr. Kendall's paper, Vol. XXXIV., Plates XIII. and XIV., of supra cit., are very instructive, the gradual change of the series being shown by parallel columns of actual sections, and finally compared with the section of the Carboniferous series at Weardale and Allen Head. The change of the Yoredale phase into that of the southern type of Carboniferous rocks is, in the West Cumberland and Furness districts, therefore demonstrated to be very gradual, and a comparison of figures representing the proportion of shale to limestone in the Furness, Egremont, and Alston Moor districts is very instructive.

The numerators represent the thickness of shale, the denominators the thickness of limestone :- 
HIND: CARBONIFEROUS KOCKS OF THE PENNINE SYSTEM. 441

$\begin{array}{ccc}\text { Furness. } & \text { Egremont. } & \text { Weardale and Allen Head. } \\ 34 & 130 & 1,602 \\ \overline{946} & \overline{75 i} & -480\end{array}$

A comparison of these amounts with other sections (page 443) which show the gradual change in the Carboniferous series as it passes north from Wensleydale to Scotland, demonstrates the same gradual change, and proves mathematically that the detrital rocks replace the organic limestones to a greater and greater extent as the beds go north.

The Cumberland-Furness area is not, however, affected by the Craven faults, which is most strong evidence against the view put forward by Mr. Tiddeman to account for the apparent sudden onset of the Yoredale phase of deposit in Yorkshire.

A theory has been advanced by him that the change from the northern to the southern type of the Carboniferous succession was largely due to the fact that the Craven faults were contemporaneous with the deposit, and in some way caused the damming back of the detrital sediments. It is difficult to see how this could have been. The Yoredale type of rocks is not seen between the Craven faults, and on the western side of the Craven area Mr. Dakyns says: "The Yoredale type of beds can hardly be said to exist south of Kettlewell" (Proc. York. Geol. and Poly. Soc., 1890, Vol. XV., p. 361). It also seems to me to be the case that the peculiar shaley beds found extending from Thornton and Barnoldswick west towards Chipping are an indication of the Yoredale phase. Then we know that the transition from the northern to the southern type is very gradual, and that the Yoredale series becomes developed gradually, and finally, although Phillips and other writers never admitted it, the whole Carboniferous series further north takes on the Yoredale phase; in fact, the Yoredale series has no true base, but the base is at a lower and lower horizon as the series passes north. If Tiddeman's view were correct, there ought to be a north and south fault in Upper Wharfedale to account for the change which takes place from east to west from Kettlewell to Fountains Fell. The change of type is there, but no fault and no barrier.

I am unable to accept the theory that the Craven faults were contemporaneous with the deposition of the beds in which the faults 
442 HiNd: CaRboniferous RoCKs OF THE PENNiNe SYSTEM.

occur. A glance at the map will show that the southern limb of the fault faults limestone unconformably against limestone, shales, grits, and coal measures, and this would surely not have been the case if the faults had been formed as the material was deposited.

In Wensleydale the Carboniferous succession is entirely different from that which obtains further south. At the base there is a mass of limestone about $500 \mathrm{ft}$. thick, with a few feet of busement conglomerate, resting on the upturned edges of the older Palæozoic rocks. This is succeeded by about $1,000 \mathrm{ft}$. of alternating shales, sandstones, and limestones, the latter being about six in number, and forming well-marked features along the escarpments of the valleys, and often giving rise to waterfalls in the tributary streams. As the beds pass north the lower undivided mass becomes split up into beds by the intercalation of shales and sandstones, and becomes the Melmerby Scar series. Coal seams are also developed at several horizons. The tendency as the beds pass north is that detrital sediment increases and limestones thin out.

The most southerly point at which any great development of these conditions occurs is in the flanks of Fountain Fell, in which the number of mappable limestones falls short of those seen in Wensleydale. On Ingleborough only four distinct beds of limestone are to be seen. The limestones of the Yoredale series are all fossiliferous, and Productus giganteus is found in all of them in Wensleydale. The intervening shales are often very fossiliferous, and contain a fauna very similar to that of the Carboniferous Limestone.

The rivers in all the great dales have cut through the Yoredale series, and splendid sections of the series are to be studied, while the collecting of fossils can be carried on in the intervening beds.

The top bed of Yoredale Limestone in Wensleydale is well seen near Leyburn, and yields a plentiful store of fish remains and other fossils. The fish all seem to belong to species which are obtained in the upper beds of the Carboniferous Limestone massif elsewhere, Psammodus, Psephodus, \&c., \&e.

The following columns show in tabular form the changes which the beds of limestone undergo as they pass north :- 
HIND: CARBONIFEROUS ROCKS OF THE PENNINE SYSTEM. 443

\begin{tabular}{|c|c|c|}
\hline$E$ & 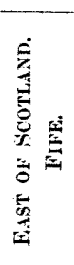 & 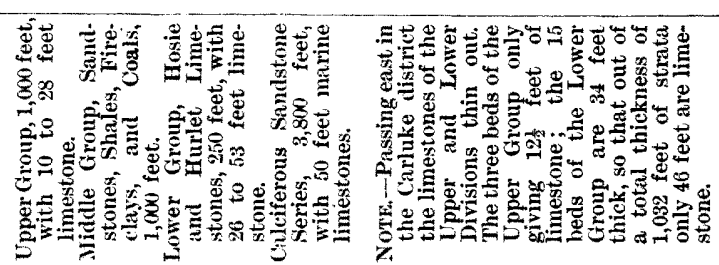 \\
\hline$=$ & 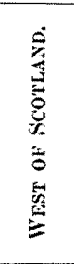 & 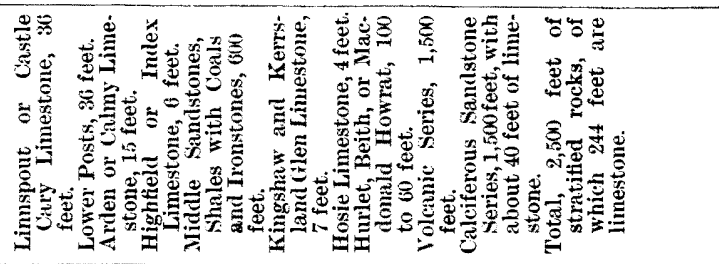 \\
\hline$\ddot{H}$ & 竞竞 & 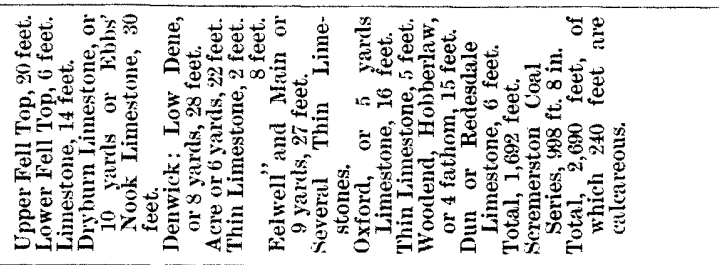 \\
\hline$\exists$ & 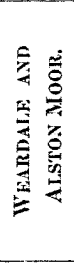 & 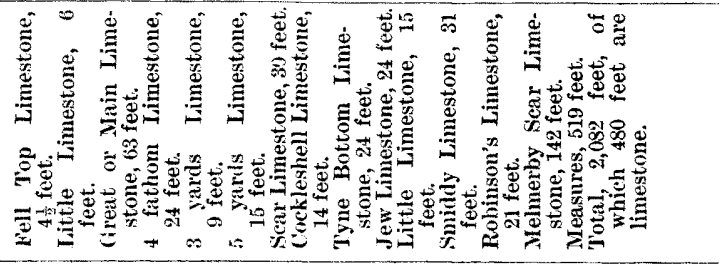 \\
\hline$\dot{H}$ & 焉 & 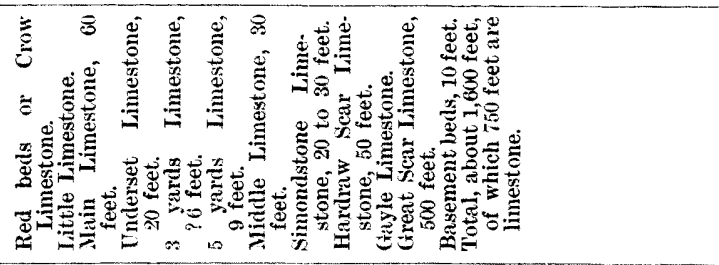 \\
\hline $\overrightarrow{t i}$ & 芯 & 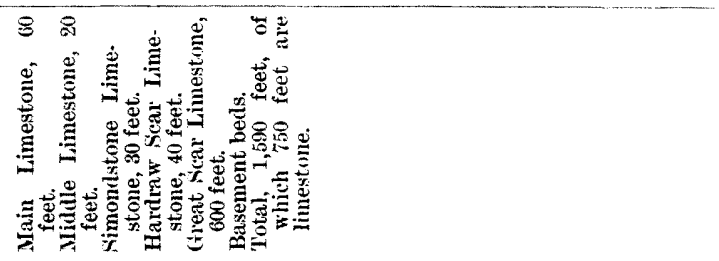 \\
\hline
\end{tabular}


444 HIND: CARBONIFEROUS ROCKS OF THE PENNINE SYSTEM.

I make no attempt to correlate the various seams, though there can be little doubt that the Main limestone of Wensleydale is represented by the great Limestone of Teesdale and Weardale, and possibly by the Dryburn Limestone of North Northumberland.

At present there is little or no paleontological evidence to prove definitely that any life zones existed in the series, or to point out, with any certainty, the exact bed of limestone which corresponds to any definite band further south. The limestones become continually split up by masses of shale as they pass north, and many of them die out, and a correlation by the numerical position of a limestone as the series, counted either from below or from above, is bound to be incorrect.

Mr. W. Gunn has attempted a precise correlation of the limestones of Dunbar and North Northumberland with the original Yoredale limestones, but it seems to me that the evidence for some of his assumptions is almost nil. The presence of an oil shale is regarded as of prime importance as a stratigraphical line in Northumberland and East of Scotland, but considering the great differences in the thickness of the purely sedimentary deposits in the two areas, it is not impossible that an oil shale was developed at a different period in the two fields. Oil shales are not unknown in the Edinburgh district at other horizons. The Oxford Limestone is stated to be the representative of the Hardraw Scar Limestone, and the Woodend and Dun Limestones are supposed to represent the Great Scar Limestone, but there is absolutely no evidence for such a correlation.

In discussing the Carboniferous section at Dunbar, Mr. Gunn says: "Opposite Pinkhead . . . there is found an impure encrinital limestone, which seems most probably to represent the Oxford. Thus nearly all the lower limestones are dying out one after the other as we proceed westward, and at Skateraw most of the thin limestones between the Oxford and the Eelwell have disappeared, while at Cat Craig the lowest limestone is the Eelwell itself. Mr. Bennie, who has collected extensively both from the Acre limestone at Lowick and from the second limestone (counting from below) at Cat Craig, has come independently to the conclusion that these limestones are the same, because they attain a similar assemblage of fossils." *

$$
\text { * (ieol. Mag., Dec. IV., Vol. V., p. } 347 .
$$


HIND : CARBONIFEROUS ROCKS OF THE PENNINE SYSTEM. 445

This is important, but unfortunately the Four Laws or Woodend Limestone at the Coomb, south of Redesdale, has yielded to Mr. Dunn and myself a fauna which contains all the special fossils (lamellibranchs and gasteropoda) which have been found at Lowick. Now, Mr. Gunn places the Four Laws Limestone much lower than the Acre. Who shall then decide whether the Cat Craig Limestones are the equivalents of the Acre or the Four Laws Limestone, more especially when it is known that the beds are undergoing rapid changes as they pass north?

It seems to me more than possible that the initial mistake in the nomenclature of the Yoredale Limestones has been to reckon them from below upwards. The Millstone Grit at the top might have been taken as a base line with a good deal more reason than the continually altering top of the Great Scar Limestone as it becomes split up by intercalations of shale to the north.

Perhaps a full and uccurate paleontological survey would give some more certain ground for correlation, though I am bound to say at present $I$ have obtained no direct evidence to enable one to approach the subject with any degree of accuracy. As the beds pass north, owing to the muddy sediment and the probable shallowing of the sea, new forms of life occur plentifully, which were not met with in the massive limestones, but similar faunas occur again and again at different horizons.

Professor Lebour has given some excellent lists of fossils from certain of the Northumberland limestones in his Handbook to the Geology and Natural History of Northumberland, from which it will be seen how very similar were the faunas obtained at different horizons. I append lists of fossils which I have obtained in the Redesdale district from the Redesdale and Four Laws Limestone series.

Professor Lebour shows that Productus giganteus is found in the Fell Top Limestone of Northumberland, but at present I have no evidence that this fossil occurs above the Main Limestone in Weardale or Wensleydale.

Last August my attention was called to a book on "The Laws which regulate the Deposition of Lead Ores," by W. Wallace, published in 1861. In it is a plate (Plate IV.) which gives his idea of the correlation of the Carboniferous deposits of England. 
446 MIND: CARBONIFEROUS ROCKS OF THE PENNINE SYSTEM.

$\mathrm{He}$ considers the Main Limestone of Weardale and the north as the equivalent of the top of the Mountain Limestone of Derbyshire, and shows the shales of Derbyshire (the Pendleside series) as being altogether above the Yoredale series.

In company with Mr. J. Barker, of Frosterley, I examined the Carboniferous succession of Weardale where quarries extending for miles on both sides of the Wear are opened in the Main Limestone, and streams and the Wear show sections from the Millstone Grit to the Four-fathom Limestone. Further west, near Wearhead, the Lower Limestones and intervening beds are exposed down to the Scar Limestone, but unfortunately I had no opportunity to examine these beds thoroughly, and they are not quarried to any extent.

Below the Fell Top Limestones, in which I got no fossils, the sandstones and gannisters were full of plant remains.

The Little Limestone is 7 feet thick, and the following section yielded the fossils enumerated below :-.-

A Bed of Quartzose Chonetes Laguessinna, Productus longispinus, Sandstone above $\quad P$. muricatus, $P$. semireticulatus, Spirifer Little Limestone, ovalis, Orthotetes crenistria, Edmondia Wolsingham.

Pattinsons Sill Sandsulcata, Lithodomus lingualis, Bellerophon (cast), Naticopsis (large cast), Phillipsia sp. (common).

storie, 12 feet.

Shale, 24 feet. Full Athyris ambigua, Chonetes Laguessiana, of round black con- Rhynchonella trilatera, Productus semicretions at base. reticulatus, Spirifera glabra, $S p$. ovalis, $S p$. trigonalis, Spiriferina octoplicata, Cypricardella anno, C. rectangularis, Bellerophon Urei, Orthoceras Morrisianum, Zaphrentis sp., Crinoid-stems.

Little Limestone, $7 \mathrm{ft}$. Chretetes radians, Syringopora geniculata, Cyathophyllum sp. Productus longispinus, Tooth of Cochliodus.

High and Low Coal Sills. 
HIND: CARBONIFEROUS ROCKS OF THE PENNINE SYSTEM. 447

Shale about 30 feet Discina nitida, Productus punctatus, Rhynbelow Little Lime- chomella pleurodon, Orthotetes crenistria, stone.

Aviculopecten sp., Allorisma sulcata, Edmondia unioniformis, Nucula gibbosa, Nuculana attenuata, Protoschizodus axiniformis, Bellerophon decussatus var. striatus, Pleurotomaria atomaria, Orthoceras sp., Fenestella sp., Crinoid ossicles.

Famps above Great Athyris planosulcata, Chonetes Laguessiana, Limestone. A few Orthis Michelini, Productus latissimus, feet only. Fenestella, and Crinoids.

Main or Great Lime- CoRALs :-Lithostrotion basaltiforme, Cyathostone, 60 to 70 feet. phyllum regium, Lonsdaleia floriformis, Clisiophyllum sp., Chaetetes radians, $C$. septosa. C. tumidus, Pyrgia sp., Syringopora ramulosa, Cladochonus sp., Athyris planosulcata, Dielasma hastata, Camarophoria crumena, Linguia mytiloides, Orthis Micheleni, Chonetes Buchiana, Productus aculeatus, $P$. cora, $P$. fimbriatus, $P$. aiganteus, $P$. latissimus, $P$. longispinus, $P$. punctatus, $P$. sinuosus, $P$. semireticulatus, Spirifera crassa, Sp.lineata, Sp.trigonalis, Sp. distans, Orthotetes crenistria, 0 . crenistria var. senilis, Rhynchonella pugnus, R. reniformis, A viculopecten colatus, Pinna flabelliformis, Allorisma sulcata, A. monensis, A. variabilis, Edmondia sulcata, $E$. unioniformis, Cypricardella anna, Sanguinolites plicatus, Solenomya costellata, S. primava, Dentalium ingens, Euomphalus pentangulatus, E. catillus, Leveillia Puzo, Loxonema sp., Macrocheilina acuta, Naticopsis plicistria, $N$. ampliata, Pleurotomaria altavittata, $P$. carinata Sow., Bellerophon cornuarietis, Actinoceras giganteum, 
Orthoceras cinctum, O. sulcatum, Temnocheilus pentagonus, Solenocheilus crassiventer (?), Phillipsia Eichwaldi var. mucronata, Phillipisia sp., Gyracanthus (spine), Psammodus porosus.

One post, known as the Frosterley marble, is made up of fine specimens of Clisiophyllum.

It may be remarked that the fauna of the Great or Main Limestone of Weardale is therefore identical with that of the Carboniferous Limestone, though containing somewhat fewer species.

The one important fact which the study of the various sections of the Carboniferous rocks given above demonstrates, is the rapid increase of detrital sedimentary deposits and the diminution of organic deposit (limestone) as the beds pass northwards.

It is found that practically no change in the nature of the deposit takes place between Derbyshire to Settle and the Craven district, but from this point northwards the change comes on rapidly. The nature of the change, the substitution of sediment obtained by the denudation of pre-existing rocks, for an organic deposit, due to living things, points without any equivocation to the cause of the change. This was the presence of continental land within a very short distance to the north of a line drawn across Scotland from the Firth of Tay to the Firth of Clyde.

I believe I am correct in stating that the most northerly deposits of Carboniferous age in Scotland are to be seen in the Pass of Brander and near Innimore of Ardtornish, on the mainland of Morvern. It is probable that the greater part of the Highlands of Scotland were dry land during Carboniferous times. The products of land erosion are deposited out at sea by the rivers which bring them down, and unless affected by strong local currents are deposited over a more or less pear shaped area, the deposit being thicker the nearer it is to the actual mouth of the river. Lighter materials are carried further out to sea, consequently shales would be laid down somewhat further from land than sandstones. The elevation of the land above the sea and its consequent effect on the rapidity of the flow of the denuding streams, will also have an important influence on the area and nature of the deposit. 
HIND: CARBONIFEROUS ROCKS OF THE PENYINE SYSTEM. 449

The Yoredale series have the following general sequence :Sandstone,

Shale,

Limestone,

and da capo, which denotes an area of clear sea unaffected by sediment, invaded by detrital mud at first, and later by heavier detrital sand. Then a condition when detrital matter was no longer carried so far south, and a return of a clear sea with conditions suitable for the environment of animals producing calcareous matter. This change may have been brought about either by the formation of a bar which prevented the carriage of sediment to the south, or an oscillation of level sufficient to permit the repeated advance and retreat of conditions from north to south and vice versa.

South of Derbyshire we know that the Lower Carboniferous rocks soon disappear. In South Staffordshire the Coal Measures rest immediately on the upturned edges of the older Palæozoic rocks. In the Coalbrookdale coalfield the whole of the Carboniferous rocks below the Coal Measures are represented by about 40 to 80 feet of limestone and 10 feet of calcareous sandstones and shales, and sandstones. At Steeraways, five miles further west, on the S.E. Aank of the Wrekin, the whole deposit is only 50 feet, showing the rapid thinning out of these beds.

There is little or no doubt that a ridge of land extended from east to west across England and Wales, and probably as far as the Wicklow Mountains, throughout Carboniferous times, too narrow and steep to supply any amount of detrital sediment, and probably the deepest part of the Carboniferous Limestone sea in the British area was a little north of this ridge. This pre-Carboniferous ridge, therefore, forms the south boundary of the great Pennine Carboniferous basin.

Of Carboniferous deposits eastward we know little or nothing, but south-east in Belgium the limestone is of very considerable thickness and is undivided by shales and sandstones, and the fauna is practically that found in the limestones of Derbyshire, Clitheroe, Cracoe, and Settle. At Clavier and Visé the limestone is succeeded by a series of shales, black limestones, sheets, and gannisters containing the typical Pendleside fauna. On the western side of 
the Pennine system, in North Wales, the Carboniferous series consists of 1,700 feet of limestone, with 250 feet of cherty sandstone, Holywell shale, 100 feet, the latter containing the fauna of the Pendleside series. No Yoredale phase, therefore. occurred in that area, and it was altogether outside the influence of the mud and sandbearing waters of the north.

Similarly the sequence in the Isle of Man shows an absence of intercalated beds of detrital sediment.

Poolvash, Posidonomya shales: Pendleside series.

Poolvash Limestone, massive, shelly, and very fossiliferous.

Well-bedded Limestones of Scarlet and Ballasalla.

And, as has been mentioned above (page 438), while in south Furness the Limestone is almost undivided by shales, as it passes north, on the west of the inlier of the older rocks constituting the Lake District, between Egremont and Penrith, masses of shale divide the limestone into well-marked beds, showing an approach to the Yoredale phase, which characterises the whole of the Carboniferous rocks from Ingleborough to the centre of Scotland.

Probably, therefore, in point of time, the thick mass of limestone in the Midlands corresponds to the Calciferous Sandstone series and Carboniferous Limestone series of Scotland, the Tuedian, Carbonaceous, and Calcareous divisions of Northumberland, and the Great Scar Limestone, plus Yoredales, of Wensleydale. The change of type in the stratification is only what might have been naturally expected to obtain in a marine area liable to be afiected by detrital material, and the two types of rocks are essentially part of one and the same story, and require no hypothetical barriers or curious contemporary earth movements to explain them.

The Pexplesine Series.

In the north Midlands the thick and undivided Massif of Limestone is overlaid by a series of dark shales with thin black and cherty limestones. These limestones gradually become obsolete higher in the series, and fine quartzose or gannister-like sandstones, with plant remains, and an occasional marine band, oceur in the shales.

This series varies from a few to 1,500 feet in thickness, and formed the main subject of the paper by Mr. Howe and myself 
HIND: CARBONIFEROUS ROCKS OF THE PENNINE SYSTEM. 451

mentioned above. Unfortunately this series was named Yoredale Series, as it was supposed to be the equivalent of the Yoredale Series of Wensleydale, but lithologically, stratigraphically, and paleontologically, the two series are quite distinct and are on different horizons.

The Pendleside Series occupies a very limited area. Its northern boundary being about a line from Greenhow Hill to Linton Mill, then passing west to a point a little south of Giggleswick, thence across the lower end of the Furness district to Poolvash, Isle of Man, and so on to Co. Meath, and across Ireland to Foynes Island, Co. Limerick.

To the south we know the series is represented in Leicestershire by a few feet of shales, and is absent along the northern margin of the Coalbrookdale coalfield. The series appears to be represented in North Wales by the Holywell Shales. The deposit is thickest at Pendle Hill, and here the greater thickness seems due to a greater amount of shales below the Pendleside Limestone, and to the greater development of the limestones. This is a purely local thickening, and within a few miles north. south, and west of Pendle the deposit is inuch thinner, and the limestones so much reduced that the officers of the Survey did not think it worth while to map them, notwithstanding the constancy of the bed, even though it was attenuated, and the strong paleontological evidence contained in it.

The characters of the limestones of the Pendleside Series are quite different from those of the real Yoredale Limestones, both in texture, chemical composition, and fossil contents. In our paper (of supra cit., pp. 394-401) one of our purposes was to show the petrological and chemical differences between the limestones of the Pendleside Series and those occurring in the dome-shaped hills of Cracoe-in-Craven, because for some, to us, unaccountable reason the latter had been correlated with the Pendleside Series, and therefore actual details of the real Yoredale Limestones were not given at that time. It may be stated here that the Yoredale Limestones agree in characters with the various beds of the thick Massif Limestone.

At the base of the series, a series of passage beds containing detrital shell material and fragments of limestone are found in places. At others shales seem to come on regularly on the top of the limestone Massif, and elsewhere evidence seems to point to masses of 
limestone being somewhat irregularly surrounded by shale. The upper limit of the series is not however so clear, for towards the top grit beds become stronger and better developed, and the typical fauna occurs again and again even as high as the Lower Coal Measures or Gannister series.

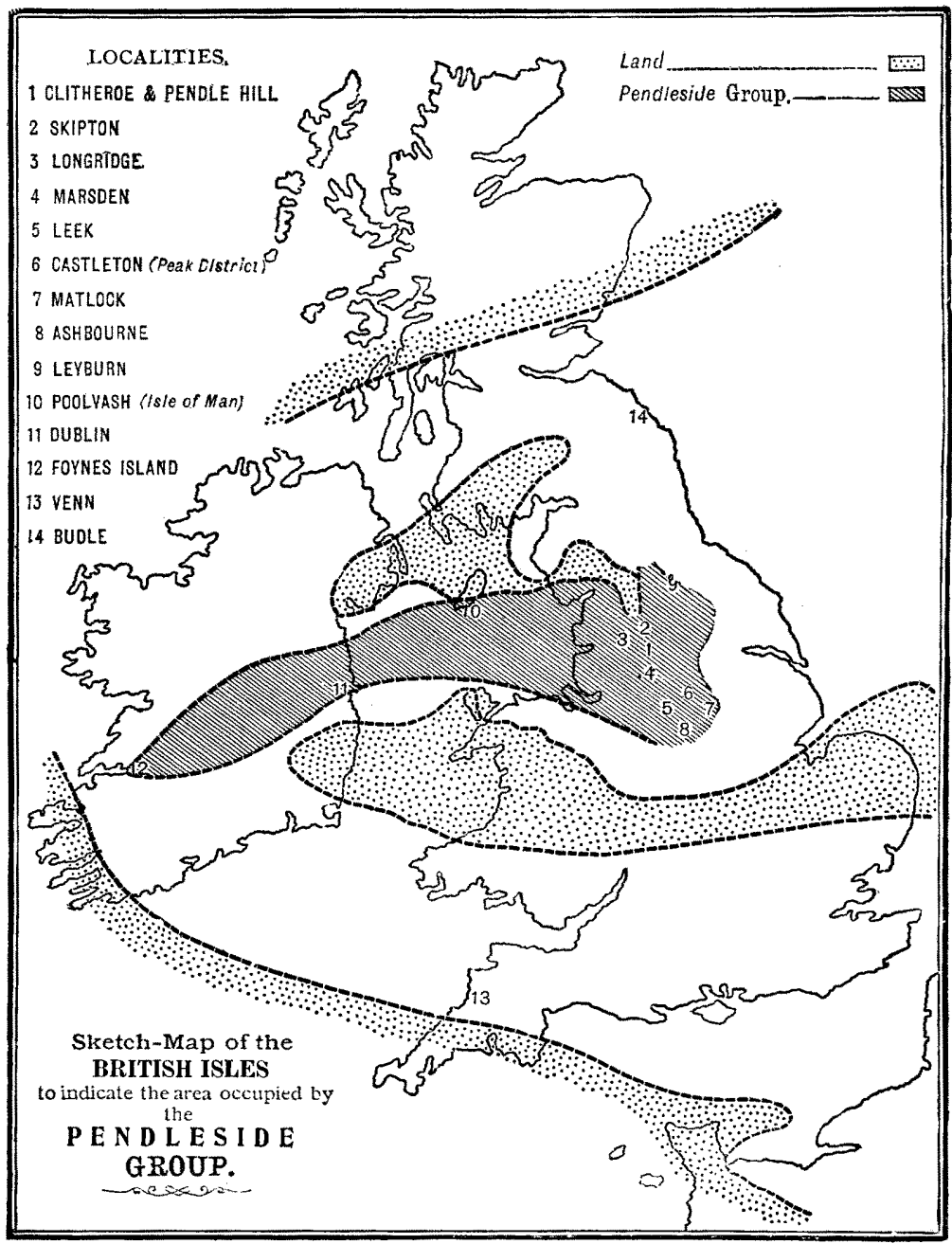

Fig. 1. 
HIND: CARBONIFEROUS ROCKS OF 'THE PENNINE SYSTEM. 453

\section{Paleontologi.}

The important evidence furnished by a study of the paleontology of the Carboniferous rocks for the correlation of the series in different districts has been very largely neglected. The extensive memoirs on the fauna and flora of different districts published by the Geological Surveys of other countries only bring home to us more forcibly the utter dearth of any such information in this country.

What is wanted now is a paleontological survey, and this could be largely carried out by local geological societies. The accurate identification of fossils is also an important desideratum. Many species published in lists have been erroneously identified, from various causes, hence the necessity for local sub-committees to superintend the correct identification of specimens.

A study of the tables of fossils published in the appendices $A$ and B to our paper (Q. J. Geol. Soc., Vol. LVII.) shows at once that the fauna of the Carboniferous Limestone is identical with that of the Great Scar Limestone plus the Yoredale Series, and further details have been published since in my report of the Committee on Life Zones in British Carboniferous Rocks (Brit. Ass. Rep., 1901).

In the same two papers it is noted that there does exist in a certain definite area, on the top of the Massif of Limestone, a series of black limestones, shales, and quartzose sandstones (the Pendleside Series), which contain a fauna peculiar and distinct from that found in the Carboniferous Limestone of the Yoredale Series. It is hinted (pp. 379-401) that the fauna of the Pendleside Series bears a very striking similarity to that of the Culm Beds of Devonshire and Europe ; a view which I am persuaded will grow clearer as fresh paleontological evidence turns up.

The percentage of fossils common to the Yoredale and the Pendleside Series is low and practically the same as that common to the Carboniferous Limestone and the Pendleside Series.

By far the greater number of the Brachiopoda of the Yoredales and the Limestone are absent in the Pendleside rocks, only some 12 species remaining.

The Actinozoa are only represented by a single species. 
The characteristic fossils of the Pendleside Series are the cephalopoda and lamellibranchs, several of which appear to be confined to the series. I regard the following species as trpical of the borizon :Dimorphoceras Gilbertsoni.

D. Looneyi.

Gastrioceras carbonarium.

G. Listeri.

Glyphioceras bilingue.

Gl. Davisi.

Gl. diadema.

Gl. reticulatum.

Gl. spirale.

Nomismoceras spirorbis.

Orthoceras Steinhaueri.

And the following lamellibranchs:---

Chonocardiola Footii.

Posidoniella lavis.

P. Kirkmani.

P. minor.

Posidonomya Becheri.

P. membranacea.

Leiopteria longirostris.

Pterinopecten papyrareus.

Aviculopecten protenuis.

Not only is the Molluscan fauna of the Fondleside Sories different from that of the Yoredales and Carboniferous Limestone, but the evidence afforded by the Vertebrate fauna is equally well marked. Dr. Traquair has shown that two totally different fish fauna, an upper and a lower, existed in Carbonferous times. The great break between these two faunas in England comes on at a line which represents the very topmost limestones of the Yoredale Series in North Yorkshire, and the topmast beds of the imestone massif in South Yorkshire and Derbyshire. The Red-beds Limestone at Leyburn has yielded a very rich fish fauna to Mr. J. Horne, and the majority of the forms found there occur also in the upper part of the massif limestone. not only in England, but in Ireland. This 
MIND: CARBONIFEROUS ROCKS OF THE PENNINE SYSTEM. 455

line extended to Scotland comes at the top of the Upper Limestone series, and it is here that the great paleontological break occurs.

I pointed out in my paper (op. supra cit., page 380) that certain genera and species are found at much lower horizons in the Carboniferous series in the north than in the south, and cited as good examples the various species of the family Nuculidæ. Nuculana attenuata and Nucula gibbosa occur in the Calciferous Sandstone series of Fife, far below the Hurlet Limestone series, or the base of the Lower Limestone series, and are also to be found recurring in calcareous shales as high as the Upper Limestone series. Nuculana attenuata appears to have come into the area some time before Nucula gibbosa. In the west of Scotland these species have not been found below the Beith Limestone series, the equivalent of the Hurlet. They appear to be absent in the Calciferous Sandstone series of Eskdale and in the Tuedian series of Northumberland, but $N$. attenuata appears in the Carbonaceous division, and both shells are plentiful at various horizons in the calcareous division.

Still further south, the lowest horizon in the Eden valley at which these two species have been found, is the shale over the Underset Limestone. Still further south the lowest horizon for $N$. attenuata is in the shales of the Pendleside series at Whitewell, while in South Yorkshire Nucula gibbosa has not heen found below the shales below the Third Grit at Eccup and Congleton Edge (Cheshire), and in North Staffordshire it occurs at one or two horizons in the Coal Measures. These two species seem to occur at higher and higher horizons as the beds pass south. We have proposed the term IsoDIETIC for the line drawn across the strata representing the migration of these shells, which denotes a life zone due to conditions rather than to time (Fig. 2.).

We have pointed out that other species and many families appear to have migrated slowly south, and for further details would refer to pages $380-385$ of that paper.

The majority of the lamellibranchs which occur in the Calciferous Sandstone series of Fife obey the same law. As I pointed out, this law obtains for byssiferous as well as for free lamellibranchs. 
Since writing my paper a very interesting fact has been discovered, which shows that plants obey the same law. Mr. R. Kidston has determined some half-dozen specimens of plants, obtained by Mr. D. Tait, from the Pendleside Series of Pendle Hill as

\section{Asterocalamites scrobiculatus, \\ Lepidodendron Veltheimianum,}

both of which species oceur in the Calciferous Sandstone Series of Fife, and apparently in that locality at that horizon only, and also a number of ferns from the Posidonomya beds of the Isle of Man, which he had never before met with above the Calciferous Sandstone Series.

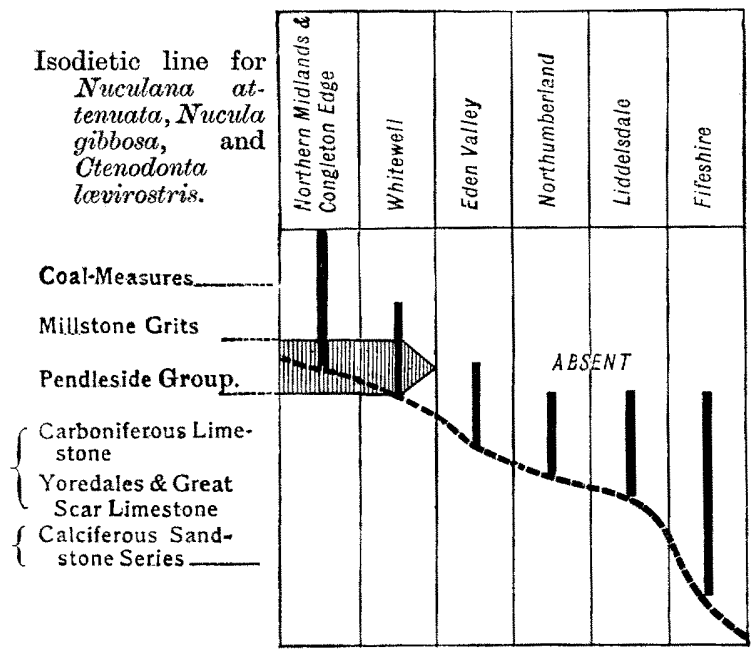

Fig. 2.

It is a remarkable fact that plants which occur very low down in the Carboniferous sequence of Fife should also occur at a much higher horizon further south. It will be interesting to ascertain if they occur, and at what horizon in the intervening country.

The fauna found in the Carboniferous Limestone massif is practically identical with that which occurs in the Great Scar and Yoredale Limestones. Some few species occur in the shales separating the limestones which have not been found in the limestone. A very 
IIND: CARHONIFEROUS ROCKS OF THE PENNINE SYSTEM. 457

natural state of things for a muddy environment would be extremely distasteful, if not fatal, to organisms which lived in a clear sea. I have never yet obtained any of the Nuculidce in pure limestones, but the species of these genera alwavs are found in muddy deposits. Of brachiopods, the Linguloe, Discina nitida, Orthis Michelini, Chonetes Laguessiana, Rhynchonella trilatera, Athyris ambigua were those most able to live in muddy waters, and are not commonly found in pure limestones.

Productus qiganteus, $P$. latissimus, Chonetes papilionacea, and Amplexus coralloides, and the great majority of the corals and Polyzoa are characteristic of the whole Carboniferous Limestone series, in which mass of rocks I have no evidence of life zones at present. For, although fossils are more numerous at the top, I cannot find that any species are confined to any definite horizon. It is probable that the rarity of fossils in the middle and lower beds of the thick massif limestone of the North Midlands is due to the fact that metasomatic changes have obliterated the fossils, but it is probable that a microscopic survey of the different beds of the massif might reveal some microscopic forms which had a limited vertical distribution. When one considers the repeated changes in the conditions of the sedimentary deposits which form the Yoredale phase of the Carboniferous rocks, it is a remarkable fact that the various limestones and marine shales are not characterised by definite fossils, but that the faunas of similar deposits at several horizons are identica!. This condition of things is doubtless due to the very local character of the deposit of shales, and that the limestone fauna had not far to migrate southward when its present habitat was rendered unsuitable for it by the incursion of muddy water, and consequently had to travel back a very short distance to that area when muddy conditions ceased. In other words the Carboniferous Limestone fauna flourished, as a whole, right through the deposit of the massive beds, and advaneed north or retreated south whenever clear conditions obtained in the area occupied by the Yoredale phase of rocks. Consequently the various limestones of the Yoredale Series contain the same faunas, and similarly the intercalated marine muds also contain the same faunas. 
458 HIND: CARBONIFEROUS ROCKS OF THE PENNINE SYSTEM.

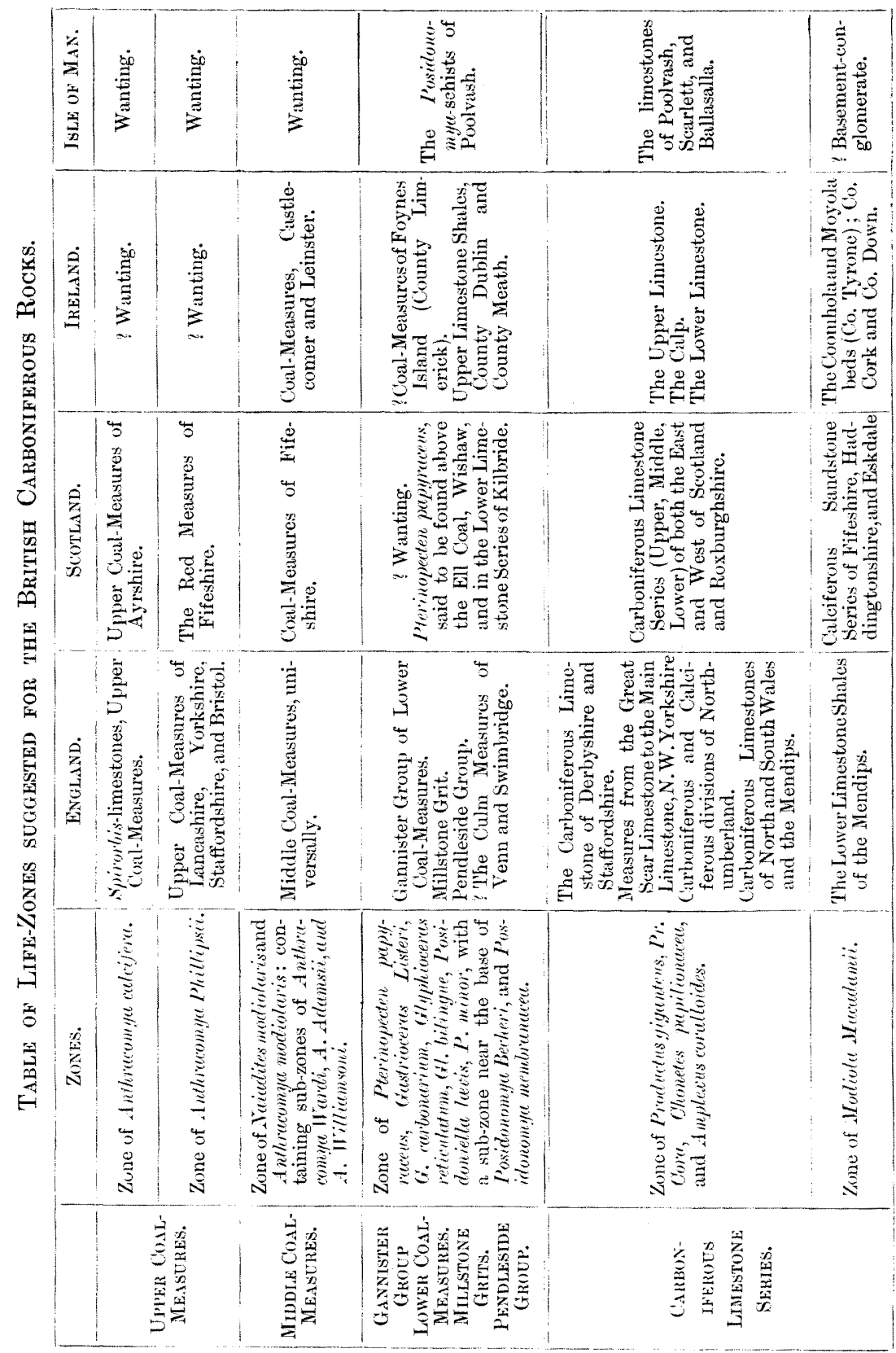



THE NORThern Midlands.

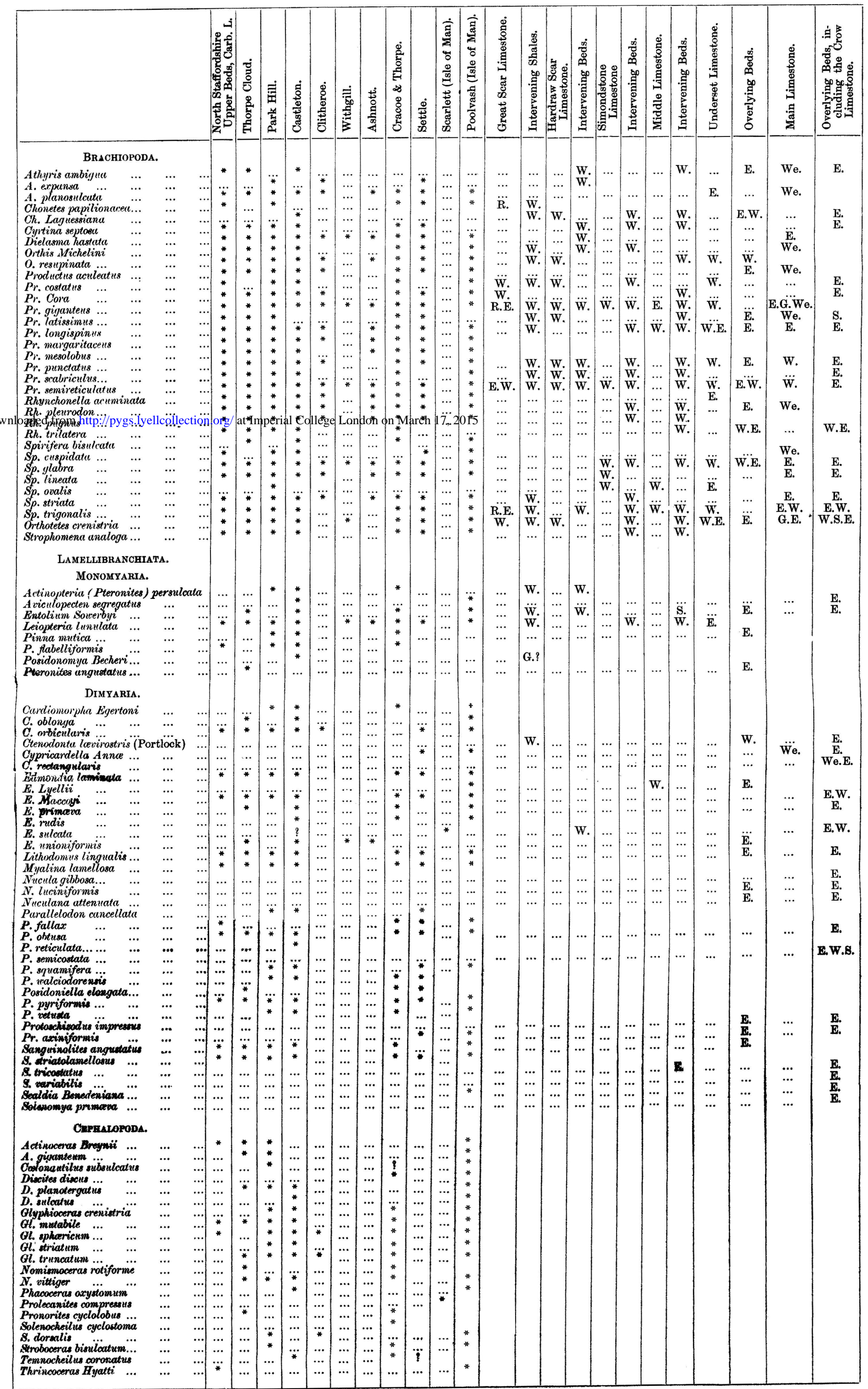




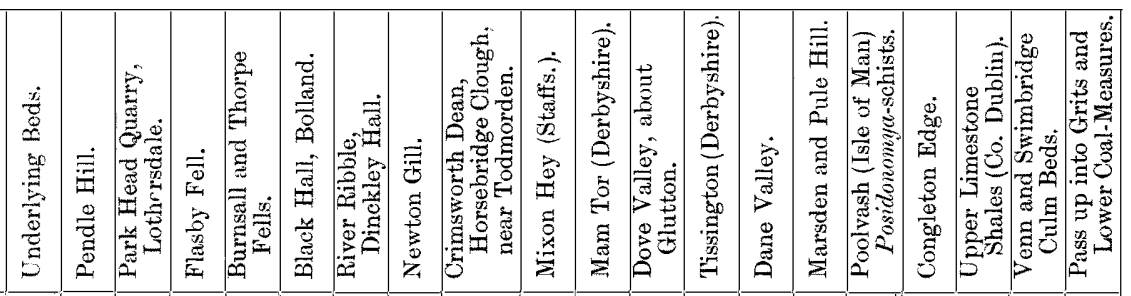

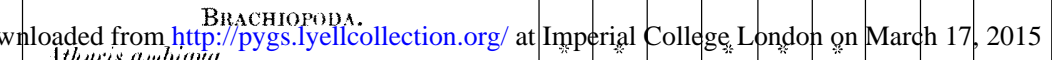

Clonetes Laguessian

Discino nitida...

Lingula secotica

Orthis Michelini

O. veserpinctete

Productes Cora..

Pr. longtspinus...

Pr. puzrotates

Pr. srabriculas ...

Rhynehonella trifatere...

Spirifere glabre.

Orthotetes crentistria

\section{LAMELJIBRANCHATA.}

Jonomyaria.

Latimenteria (Pteronites) persulcata...

Prestinupreten petpyraceus $\dagger$

Anculopsten pretenuis

Leiopteritu longirostris

Posidonemina Berhein

P. montirencesed

\section{DIMYARIA.}

Chesecendishe Footii

Ctenodonte leverrostris Portl.

Miguliat Fleningt

1.. perctute

I. Ternetilit

Viecrala cequalis...

N. gibbose

Vercetand stilla.

Pestidoniella lexis

P. Kirkmani

P. minos

Surguinalites tritostatus

Solvizodus antiquets

Solenomiza costellatus

Sedgrichice attenzata

Cephalopoda.

\section{Dimurphocerces Gilbertsoni}

\section{Looneit}

Ephippioceres clitellaritu

Gustrioceres carbonarim

G. Listeri:

Glyphiocerce bilingue

Gi. Davisi

Gl. diadema

Gl. implicatum

Gl. nitidum

Gl. Phillipsit

Gl. veticulatum

Gl. spirale

Gl. stenolobum

G1. vesica

Vomisntoceres spirorbis

Orthoceras aciculare Brown

o. Kominchianum

O. Steinhateri

O. sulcatum

Prolectnites compresesus

Pr. serpentinus

Temnotheilus curbonarius

T. comerews.

\section{Gasteropoda.}

Bellerophon Ure:

Matrocheilina elegutis

M. Tribsoni

M. reficellate

PISCES.

Acrolepis Hophlinst

Cladodus sp.

Elonichthess ditheni

Oroxles sp.

†It is to be regretted that the name Aviculopecten will have to be changed for this shell. Revision of the Perten-like shells of the Carboniferons rocks shows that several distinet genera have been included under Ariculoperten the type of which, A. p/etirmetiatus, differ much fron A. papyraceus, which should probably be referred to Pterinopecten of Hall. 
HIND: CARBONIFEROUS ROCKS OF THE PENNINE SYSTEM. 463

APPENDix C.

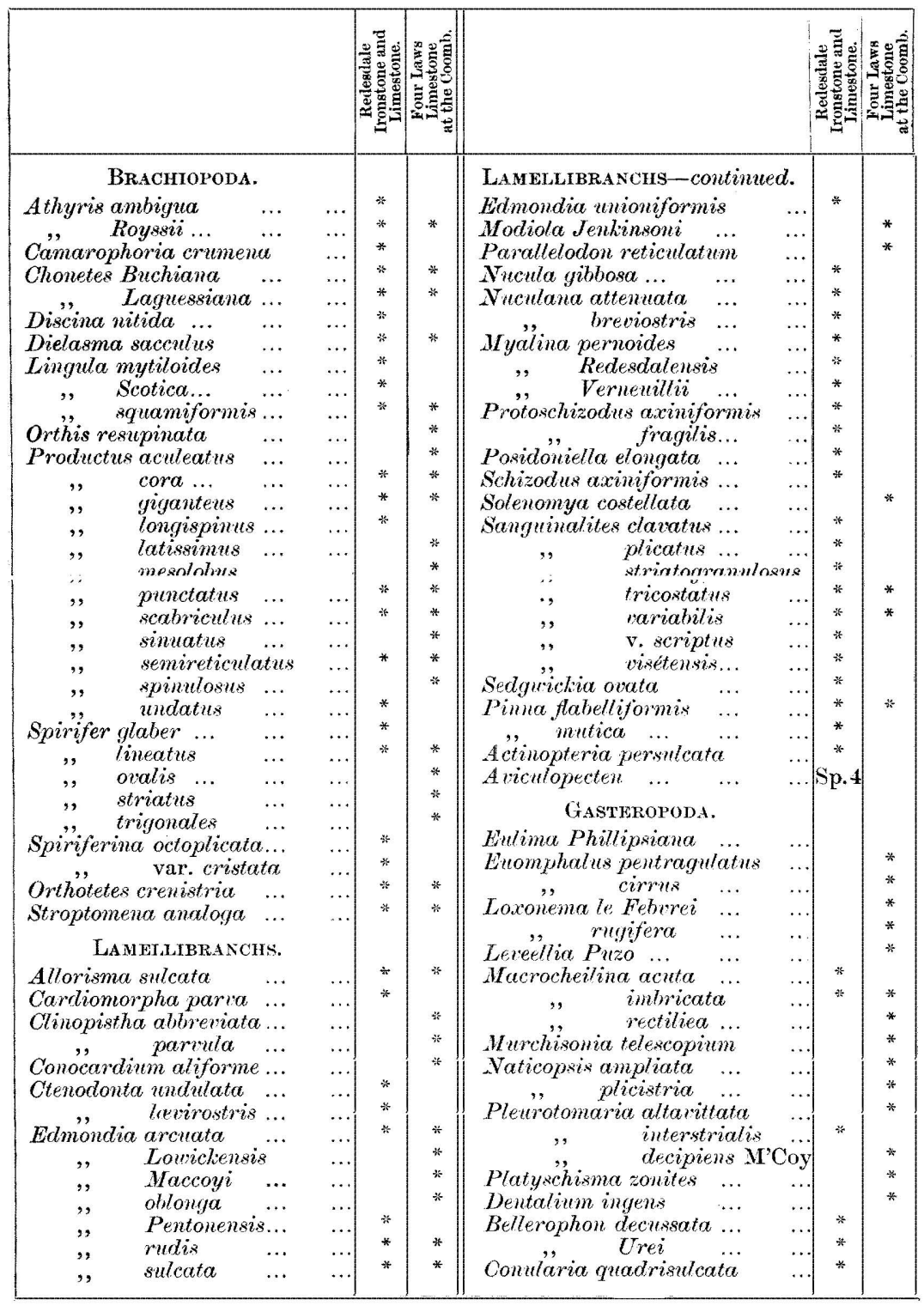


464 HIND: CARBONIFEROUS ROCKS OF THE PENNINE SYSTEM,

APPENDIX C-continued.

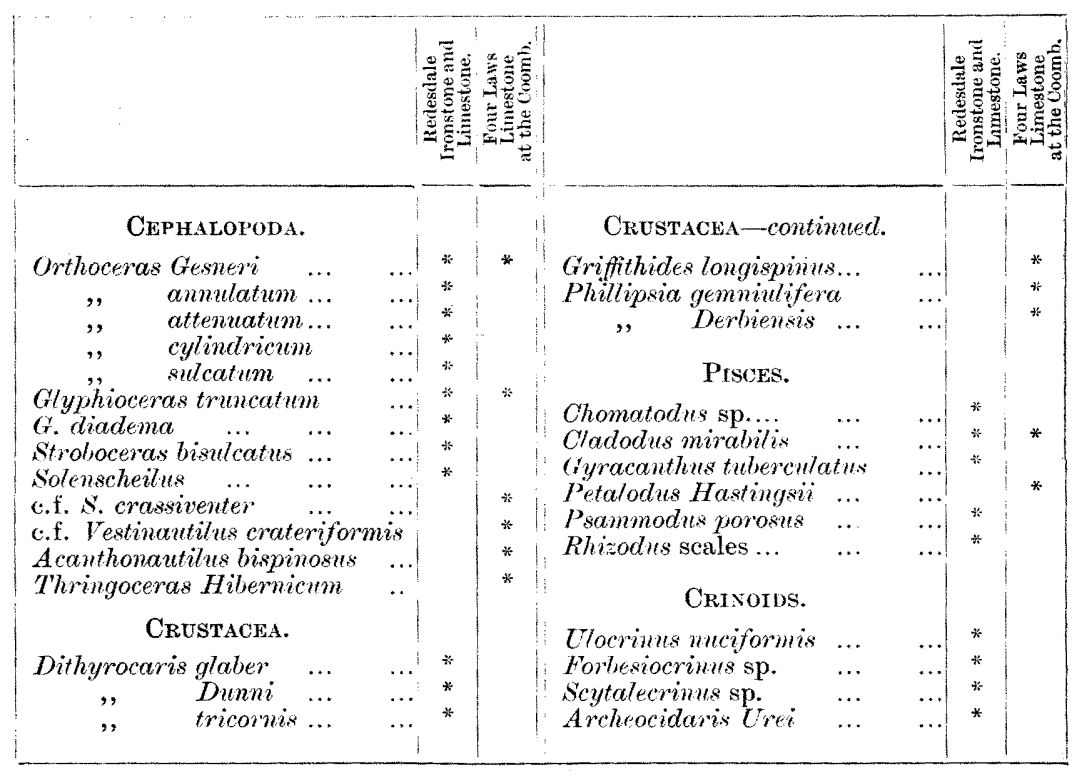

My thanks are due to the Geological Society for permission to reprint Fig. 1, p. 452, and Fig. 2, p. 456. 